\title{
Gerakan Kontra Pembangunan Shelter 9 Dan 10 Pltu Suralaya Merak-Banten
}

Nida Urrohmah ${ }^{1}$

FISIP Universitas Sultan Ageng Tirtayasa

nidaurrohmah1234@gmail.com

Karin Caroline Kelly ${ }^{2}$

FISIP Universitas Sultan Ageng Tirtayasa

karincarolkelly@gmail.com

Fitri Yuliani ${ }^{3}$

FISIP Universitas Sultan Ageng Tirtayasa

fitriyuliani1515@gmail.com
E-ISSN (2721-0642)

Recieved:

June 022020

Revised:

August 142020

Accepted:

August 192020

Doi Number

10.37950/ijd.v2i2.54

\section{Abstract}

Electric Steam Power Plants (PLTU) need coal as fuel to produce electricity. The higher the electrical energy needed to eat, the more fuel will be used. This has happened in the construction of shelters 9 and 10 Suralaya Merak-Banten steam power plant (PLTU). This development is reaping various kinds of rejection because it causes environmental damage not only in the area around the development operation but also in the Greater Jakarta area. The rejection movement was initiated by local residents and supported by international Environmental NGOs.

Keyworrds: counter movement, development, suralaya steam power plant (PLTU)

\begin{abstract}
Abstrak
Pembangkit Listrik Tenaga Uap (PLTU) membutuhkan batu bara sebagai bahan bakar untuk menghasilkan energi listrik. Semakin tinggi energi listrik yang dibutuhkan makan akan semakin banyak bahan bakar yang digunakan. Hal ini terjadi pada pembangunan shelter 9 dan 10 PLTU Suralaya di pulau Jawa spesifiknya di daerah
\end{abstract}


Merak-Banten. Pembangunan ini menuai berbagai macam penolakan karena mengakibatkan kerusakan lingkungan tidak hanya pada wilayah sekitar operasi pembangunan namun juga pada wilayah Jabodetabek. Gerakan penolakan diinisiasi tentunya oleh warga setempat dan didukung dengan NGO Internasional penggiat isu lingkungan.

Kata Kunci : gerakan kontra, pembangunan, PLTU Suralaya

\section{Pendahuluan}

Permintaan akan listrik semakin meningkat tiap tahunnya terkait dengan perkembangan ekonomi dan peningkatan standar hidup di setiap negara. Listrik menjadi suatu kebutuhan tak terbantahkan dalam aktivitas hidup manusia. Tanpa adanya listrik, akan berdampak pada terhambatnya berbagai proses kegiatan dalam kehidupan bermasyarakat, baik dari sektor rumah tangga hingga aktivitas lingkup negara. Keberadaan listrik sudah menjadi suatu hal yang paling penting dan mendasar untuk dipenuhi oleh negara. Tingginya permintaan listrik berlaku untuk negara-negara berkembang termasuk Indonesia di mana konsumsi listrik jauh di bawah rata-rata konsumsi listrik di negara-negara industri.(Xue,dkk, 2005) Untuk memenuhi peningkatan permintaan itu, maka langkah yang ditempuh adalah membangun pembangkit listrik baru, yang dapat secara optimal memenuhi kebutuhan listrik sesuai dengan kriteria yang diberlakukan. Kriteria utama tersebut antara lain: potensi untuk memasok energi yang dibutuhkan, memasok energi dengan biaya minimal, memenuhi persyaratan perizinan dan dapat diterima oleh publik. (Feretic \& Tomsic, 2005)

Terdapat berbagai pilihan mengenai sumber bahan utama produksi listrik, yang paling populer selama beberapa dekade untuk dijadikan bahan dasar pembangkit listrik ialah batu bara, gas, dan nuklir. Di samping itu, ada pembangkit listrik terbarukan yang berasal dari matahari, angin, dan bio massa, namun pembangkit listrik dari sumber ini belum menjadi perhatian mendalam bagi pemerintah khususnya di Indonesia karena alasan potensi pasokan energi yang terbatas dan biaya tinggi. Sementara pembangkit tenaga air hanya bisa diterapkan di daerah-daerah yang memiliki potensi air dengan debit cukup besar. Atas pertimbangan hal tersebut, hingga kini Indonesia masih memilih menggunakan energi batu bara sebagai bahan dasar produksi listrik dengan alasan lebih ekonomis dan cocok dijadikan sebagai sumber energi listrik.

Namun sayangnya, penggunaan batu bara sebagai bahan baku produksi listrik memiliki berbagai dampak buruk, Khususnya bagi lingkungan. Batu bara yang telah melalui proses pembakaran di PLTU (Pembangkit Listrik Tenaga Uap) menghasilkan polusi, diantaranya ialah $\mathrm{NOx}$ dan $\mathrm{SO}^{2}$ yang menjadi penyumbang terbesar terbentuknya hujan asam serta Polusi PM2.5. Dari proses pembakaran batu bara, memberikan dampak polusi yang tinggi seperti diungkapkan oleh International Energy Agency (IEA) bahwa Emisi CO $\mathrm{CO}^{2}$ global yang bersumber dari batu baru ialah sekitar $44 \%$ dan memicu perubahan iklim melalui emisi gas rumah kaca. Selain itu, pengelolaan batu bara oleh PLTU juga menghasilkan paparan bahan kimia berbahaya seperti arsen 
dan merkuri yang memiliki dampak kesehatan terhadap masyarakat yang tinggal di sekitar lingkungan proyek PLTU. (Greenpeace, 2015)

Atas dasar implikasi terhadap polusi lingkungan, banyak negara di belahan dunia mulai beralih dari energi batu bara ke energi lain yang lebih ramah lingkungan, sehingga penggunaan batu bara sebagai bahan dasar produksi listrik tidak lagi menjadi tren dunia. Namun di tengah menurunnya tren penggunaan batu bara, Indonesia masih menjadi negara yang konsisten mempertahankan batu bara sebagai energi produksi listrik, padahal jumlah cadangan batu bara di Indonesia hanya memiliki cadangan 3\% dari jumlah batu bara dunia.

Di tengah permintaan kebutuhan listrik yang terus naik rata-rata $9 \%$ tiap tahunnya dan sudah menjadi kewajiban negara dalam memenuhi hal tersebut, Sehingga strategi yang dilakukan oleh pemerintah Indonesia ialah dengan mempercepat program pembangunan tahap I yakni pembangunan PLTU 10.000 Mega Watt (MW). strategi percepatan yang dilakukan oleh Pemerintah mengacu pada Perpres (Peraturan Presiden) No. 7 tahun 2006 mengenai regulasi terkait tugas yang harus dilakukan oleh PT PLN (Perusahaan Listrik Negara) guna mempercepat pembangunan PLTU dengan bahan dasarnya ialah batu bara. Percepatan pembangunan ini merupakan proyek besar guna memasok energi yang dapat diakses oleh seluruh masyarakat Indonesia, yang pembangunannya dilakukan di Pulau Jawa. Proyek pembangunan PLTU secara besar dengan skala nasional ini dikenal dengan proyek pembangunan PLTU JAMALI (Jawa, Madura, Bali). Berikut adalah tabel mengenai proyek pembangunan PLTU berskala nasional:

Tabel 1.

\section{Proyek Pembangunan PLTU Nasional}

\begin{tabular}{|l|l|l|}
\hline PROYEK PLTU & LOKASI & KAPASITAS \\
\hline PLTU SURALAYA BARU & Cilegon, Banten & $1 \times 625 \mathrm{MW}$ \\
\hline PLTU LABUAN & Pandeglang, Banten & $2 \times 300 \mathrm{MW}$ \\
\hline PLTU LONTAR & Tangerang, Banten & $3 \times 315 \mathrm{MW}$ \\
\hline PLTU INDRAMAYU & Indramayu, Jawa Barat & $3 \times 330 \mathrm{MW}$ \\
\hline PLTU PALABUHAN RATU & Sukabumi, Jawa Barat & $3 \times 330 \mathrm{MW}$ \\
\hline PLTU ADIPALA & Cilacap, Jawa Tengah & $1 \times 660 \mathrm{MW}$ \\
\hline PLTU REMBANG & $\begin{array}{l}\text { Rembang, Jawa } \\
\text { Tengah }\end{array}$ & $2 \times 315 \mathrm{MW}$ \\
\hline PLTU PACITAN & Pacitan, Jawa Timur & $2 \times 315 \mathrm{MW}$ \\
\hline $\begin{array}{l}\text { PLTU TANJUNG AWAR- } \\
\text { AWAR }\end{array}$ & Tuban, Jawa Timur & $2 \times 350 \mathrm{MW}$ \\
\hline PLTU PAITON BARU & $\begin{array}{l}\text { Probolinggo, Jawa } \\
\text { Timur }\end{array}$ & $1 \times 660 \mathrm{MW}$ \\
\hline
\end{tabular}

Sumber: (Baskoro, Galih Honggo, 2013)

PLTU Suralaya Baru yang bertempat di Provinsi Banten menjadi salah satu proyek andalan percepatan listrik di Pulau Jawa yang dibangun dengan kapasitas besar 
yakni 1 x 625 MW. Pada proyek ini, PLTU Suralaya menambah 2 shelter baru yakni shelter 9 dan 10 sebagai bentuk upaya dari program pembangunan PLTU nasional tersebut. Pembangunan ini tentunya menghasilkan pro dan kontra di berbagai pihak. Di satu sisi pembangunan ini sebagai upaya penambahan kapasitas listrik di wilayah Pulau Jawa, namun di sisi lainnya memberikan dampak buruk yang sangat besar terhadap lingkungan dan kesehatan akibat aktivitas produksi pembakaran batu bara oleh PLTU. Pemerintah Indonesia pada umumnya, dan Pemerintah daerah pada khususnya, belum secara maksimal menyadari berbagai dampak buruk yang ditimbulkan dari proses pembakaran batu bara yang telah dijelaskan sebelumnya. Di berbagai belahan dunia, salah satunya Amerika, telah menggerakan energi bersih di mana penggunaan energi yang merusak keseimbangan alam telah diminimalisir. Hal ini dilatarbelakangi oleh kesadaran masyarakat bahwa produksi pembakaran batu bara sangat berbahaya bagi kondisi kesehatan lingkungan dan masyarakat serta makhluk hidup lainnya. Masyarakat disana melakukan sebuah gerakan penolakan besar-besaran terhadap pembangunan PLTU sehingga mengakibatkan sebanyak 200 PLTU telah ditutup (Greenpeace, 2015). Gerakan energi bersih ini coba digencarkan juga oleh masyarakat terdampak pencemaran PLTU Suralaya di Merak, Banten. Mereka menilai setiap polusi yang dihasilkan oleh aktivitas PLTU akan berdampak buruk bagi keseimbangan ekosistem lingkungan dan kesehatan masyarakat di sekitar proyek PLTU Suralaya.

Nitrogen Oksida (NOx) senyawa yang dikenal dalam pencemaran lingkungan ditemukan di daerah Banten dengan jumlah pencemaran yang tinggi, pencemaran ini tidak hanya berlaku di Provinsi Banten namun terjadi pula pada wilayah pulau Jawa dengan angka tertinggi khususnya wilayah Jabodetabek (Jakarta, Bogor, Depok, Tangerang, Bekasi). Pencemaran disebabkan oleh adanya pembangunan PLTU shelter 9 dan 10 yang berlokasi di Merak-Banten. Pencemaran yang tinggi diakibatkan karena jarak pembangunan PLTU cukup dekat yaitu berkisar antara $100 \mathrm{~km}$ pada wilayah yang terdampak. Dibuktikan dengan pemberitahuan dimulai dari bulan November sampil April emisi batu baru yang dihasilkan karena pembangunan PLTU shelter 9 dan 10 Suralaya terbawa angin menuju wilayah Jabodetabek sedikitnya membuat sekitar 30 juta penduduk terpapar polusi udara berbahaya.

Paparan polusi diperburuk dengan fakta bahwa wilayah jabodetabek merupakan wilayah padat industri di mana terdapat polusi industri yang diakibatkan oleh aktivitas produksi pabrik. Pencemaran lingkungan yang berdampak kepada kerusakan lingkungan sekitar sangat dirasakan oleh masyarakat, adapun menurut beberapa sumber diperkirakan bahwa pembangunan PLTU Suralaya shelter 9 dan 10 memiliki risiko yang memicu bencana iklim global yang disebabkan oleh kenaikan suhu sebesar 1,5 derajat celcius (WALHI, 2018).

Keadaan selanjutnya yang menjadi dampak dari pembangunan Pembangkit Listrik Tenaga Uap Shelter 9 dan 10 dirasakan oleh masyarakat yang tinggal dekat wilayah pembangunan. Mereka mengatakan bahwa pembangunan tersebut mengakibatkan adanya abu yang beterbangan (fly ash) ke wilayah pemukiman sehingga memberikan efek gangguan saluran pernafasan akut (ISPA). Wilayah permukiman yang memiliki jarak kurang dari satu meter kilometer dari lokasi pembuangan 
sementara limbah beracun milik Pembangkit Listrik Tenaga Uap Suralaya shelter 9 dan 10 Merak-Banten menjadi penyebab yang mengganggu kesehatan masyarakat wilayah sekitar. (Arefana,2019)

Lokasi tempat pembuangan sementara hanya berjarak 1 kilometer dengan kondisi limbah yang menumpuk hingga ketinggian 100 meter. Posisi Tempat Pembuangan Limbah Sementara atau B3 kepunyaan PLTU Suralaya berada pada area terbuka, hal dapat dilihat oleh masyarakat dan pengguna jalan yang melewati kawasan tersebut. Upaya meminimalisir penyebaran abu pada wilayah sekitar disediakan area untuk menyiram abu yang ditimbun. Namun hal ini tidak berjalan seperti seharusnya dikarenakan hingga debu mencapai hingga ke jalan raya. (Koran Tempo, 2018). Diketahui tiga lembaga investasi besar dari Korea Selatan telah memberi investasi sebanyak 3 Miliar US Dollar guna mendanai pembangunan 2 ribu MW milik Pembangkit Listrik Tenaga Uap Suralaya Shelter 9 dan 10 Merak-Banten. Tiga investor tersebut yaitu; Korea Export-Import Bank, Korea Trade Insurance Corporation dan Korea Development Bank. Selanjutnya, potensi batu bara yang digunakan untuk pembangunan Pembangkit Listrik Tenaga Uap Suralaya Shelter 9 dan 10 berkapasitas 2 ribu MW dibutuhkan setidaknya 1,100 Ton perjam batu bara yang harus menjadi bahan bakar untuk pengoperasian PLTU. Sehingga Jika diakumulasi membutuhkan lebih dari 9 juta ton pertahun (CNN Indonesia, 2019).

Kondisi yang diakibatkan karena pembangunan PLTU shelter 9 dan 10 di pulau jawa ini tentu saja berakibat dengan adanya gerakan penolakan yang dilakukan oleh warga sekitar. Selain dampak negatif seperti merusak lingkungan pembangunan ini dinilai memberikan potensi kerugian ekonomi pada negara karena biaya produksi sangat tinggi. Adapun gerakan penolakan dilakukan oleh warga didampingi pula dengan organisasi penggiat lingkungan Trend Asia, Walhi dan Greenpeace.

Karena adanya dampak negatif sosial dan lingkungan dari pembangunan shelter 9 dan 10 PLTU Suralaya Merak-Banten. Peneliti merasa tertarik untuk menelaah topik ini. Penelitian ini di fokuskan pada gerakan organisasi penggiat lingkungan yaitu NGO Trend Asia dalam menolak pembangunan PLTU Suralaya Shelter 9 dan 10.

\section{Kerangka Teori}

\section{Gerakan Sosial Baru}

Gerakan sosial merupakan sebuah konsep yang dalam perkembangannya mengalami banyak pembaharuan, diantaranya pembaharuan dari gerakan sosial ialah lahirnya konsep gerakan sosial baru. Gerakan sosial didefinisikan Giddens sebagai sebuah usaha secara bersama-sama dengan menggunakan tindakan bersama serta menempatkan diri di luar gerakan yang diinisiasi oleh pemerintah guna mencapai kepentingan bersama (Suharko, 2006).

Pada tahun 1970-an menjadi awal kemunculan gerakan sosial baru di Amerika dan Eropa. Gerakan sosial baru lahir di tengah masyarakat kontemporer, lahirannya gerakan sosial baru ini merupakan wujud kritik dari gerakan sosial lama. Kemunculan gerakan sosial baru ini ditandai dengan munculnya gerakan sosial yang memperjuangkan serta mengedepankan hak sipil dari warga negara. Gerakan sosial baru lahir atas keadaan sosial yang terjadi pada masa itu, di mana banyaknya tindakan- 
tindakan penindasan serta represif. Sehingga yang menjadi orientasi dari gerakan sosial baru ialah mengenai permasalahan penindasan serta tindakan represif yang dilakukan oleh suatu lembaga. Kunci utama dalam gerakan sosial baru ialah masalah struktur sosial. Adapun struktur sosial yang dipahami dalam gerakan sosial baru ialah tindakan yang membentuk suatu pola, hubungan, yang diabstraksi serta terdapat dalam posisi independen yang terdiri atas motivasi individu (Rusmanto, 2013). Sebagai sebuah kritik atas gerakan sosial lama, maka yang menjadi isu-isu dalam gerakan sosial baru merupakan isu-isu yang orientasinya lebih luas serta kepentingan yang berada di dalamnya lebih luas pula. Sifat utama dalam gerakan sosial baru ialah plural, artinya dalam gerakan sosial baru banyak memperjuangkan terkait isu mengenai anti nuklir, pelucutan senjata, anti rasisme, isu-isu feminisme, isu kebebasan sipil, memperjuangkan perdamaian serta mengenai isu lingkungan (Singh, 2007).

Gerakan sosial baru dalam konsepnya menentang konsep dari Marx yang mendasari sebuah perjuangan berdasarkan konsep kelas. Gerakan sosial baru dalam taktik serta pengorganisasiannya menggunakan cara-cara yang disruptive (mengganggu), menggunakan hubungan-hubungan di luar politik yang normal, serta guna mendapatkan daya tawar politik menggunakan cara mobilisasi opini publik. Gerakan sosial baru bersifat plural, sehingga yang menjadi partisipan dari sebuah gerakan sosial baru tidak berdasarkan penggolongan kelas tertentu, di mana yang menjadi partisipan dalam gerakan sosial baru ialah individu-individu yang bergerak guna kepentingan kemanusiaan yang terdiri atas beragam kategori dan status sosial (Singh, 2007). Kebebasan menjadi dasar dari gerakan sosial baru, sehingga dalam gerakan sosial baru tidak terbirokratisasi, tidak adanya struktur organisasi, karena inti dari gerakan sosial baru ialah individu-individu yang memiliki kepentingan serta kesamaan isu yang diperjuangkan. Identitas politik yang tercipta dari partisipanpartisipan gerakan sosial baru ialah berfokus pada upaya menekan pemerintahan untuk tidak mementingkan kepentingan material semata (Prasetya dan Suprayogi, 2019).

Dalam memahami konsep gerakan sosial baru, dapat dilakukan dengan menggunakan pendekatan-pendekatan yang relevan. Adapun pendekatan-pendekatan yang relevan guna memahami konsep gerakan sosial baru, antara lain proses framing, teori struktur kesempatan politik, struktur mobilisasi serta teori keluhan. Dalam kasus mengenai pembangunan shelter 9 dan 10 PLTU Suralaya yang menuai berbagai pro dan kontra, maka pendekatan yang paling relevan ialah mengenai teori keluhan.

\section{Pendekatan Teori Keluhan}

Teori keluhan ialah sebuah teori yang banyak digunakan guna menjabarkan mengenai gerakan sosial dan juga bentuk-bentuk lain dari politik perlawanan, teori keluhan merupakan sebuah pembaharuan teori dari teori eksploitasi kelas (Situmorang dan Wahib, 2007). Teori keluhan dianggap relevan dengan topik penelitian dalam tulisan ini dikarenakan lahirnya gerakan sosial baru ialah atas dasar keluhan yang baru. Hadirnya isu-isu baru yang bersifat plural, membuat lahirnya keluhan-keluhan baru yang kemudian menciptakan sebuah gerakan sosial yang baru pula. 
Faktor pendorong terciptanya sebuah keluhan baru dikarenakan permasalahan ketidak seimbangan sosial, baik secara sistematik (makro) maupun individu (mikro). Permasalahan tersebutlah yang menjadi akar terciptanya gerakan sosial baru. Alfred Russel Wallace menyebutkan bahwa ketidak seimbangan sosial hadir berdasarkan beberapa faktor, yang diantaranya ialah (Situmorang dan Wahib, 2007):

1. Konflik internal, faktor ini menyebabkan sebuah kerugian besar yang dilakukan oleh kelompok-kelompok yang berkepentingan terhadap kelompok masyarakat.

2. Perang. Faktor ini hadir dikarenakan dampak yang terjadi pasca perang, yakni membuat sumber daya ekonomi dari kelompok masyarakat menjadi habis.

3. Perubahan iklim. Terjadinya perubahan iklim dapat membuat perubahan di dalam ekosistem, di mana dapat menyebabkan hancurnya struktur makhluk hidup.

4. Wabah penyakit. Faktor ini membuat terjadinya perubahan bahkan kehancuran dalam struktur populasi.

5. Subordinasi serta posisi yang inferior dalam kelompok masyarakat.

Relevansi dari teori keluhan dengan gerakan sosial lingkungan yang menjadi pembahasan dalam penulisan penelitian ini ialah adanya degradasi lingkungan yang terjadi secara besar-besaran yang terjadi diseluruh belahan dunia dan tidak terkecuali Indonesia salah satunya. Kerusakan-kerusakan lingkungan terjadi berdasarkan beberapa alasan, yakni: pencemaran, baik air maupun udara; penggundulan hutan yang membuat banyak terjadinya bencana longsor; serta kerusakan lingkungan lainnya yang menyebabkan terjadinya kekeringan dan banjir. Kerusakan-kerusakan lingkungan yang terjadi tidak hanya berimbas kepada tumbuhan dan hewan saja, terlebih berimbas kepada kehidupan manusia. Sehingga hal-hal tersebutlah yang kemudian memunculkan sebuah keluhan dari masyarakat, selanjutnya keluhan-keluhan masyrakat tersebut mendorong terciptanya gerakan sosial lingkungan sebagai bentuk dari gerakan sosial baru (Situmorang dan Wahib, 2007).

Keberadaan PLTU Suralaya Shelter 9 dan 10 hadir karena adanya konflik internal yang hadir dalam proses pembangunan PLTU Suralaya ini ialah antara masyarakat dan investor yang mendanai keberlangsungan proyek. Proyek ini juga secara langsung melibatkan pemerintah indonesia. Berangkat dari konflik yang melibatkan ketiga aktor yang seperti disebutkan di atas. Masyarakat menjadi subjek yang dirugikan dengan pembangunan PLTU Shelter 9 dan 10 Suralaya. Pasalnya pembangunan ini memberikan dampak yang sedemikian buruk. Contohnya, debu sisa produksi batu baru mengakibatkan tanaman disekitar warga rusak. Selanjutnya, limbah dari proses produksi batu bara menimbulkan polusi udara yang dapat menganggu saluran pernafasan manusia, jika dibiarkan dalam jangka panjang dapat mengakibatkan kematian. Dengan fakta ini membuktikan bahwa pembangunan PLTU Suralaya menjadi faktor terjadinya wabah penyakit terhadap warga yang bermukim dekat dengan lokasi PLTU.

Beberapa fakta diatas menjadi keluhan utama masyarakat sekitar mengenai pembangunan PLTU Shelter 9 dan 10 Suralaya Merak-Banten. Maka dari itu sejumlah penggiat lingkungan turun tangan dan ikut andil dalam protes pemberhentian pembangunan PLTU Suralaya Merak Banten. Keberadaan emisi batu bara yang dihasilkan dari proses produksi PLTU Suralaya dapat mengakibatkan kenaikan suhu 
sebesar 1,5 derajat celcius yang memicu terjadinya bencana iklim global dikemudian hari dan dapat menjadi salah satu faktor perubahan iklim kemudian mengancam struktur makhkuk hidup.

Dari lima faktor pendorong terciptanya sebuah keluhan, dalam kasus ini Pembangungan PLTU Shelter 9 dan 10 Suralaya merak banten telah memenuhi tiga diantaranya yaitu, konflik internal, perubahan iklim dan wabah penyakit.

\section{Poltik Lingkungan}

Lingkungan hidup jika dilihat dari kacamata politik, maka perlu ada sebuah konsep serta kerangka pemikiran teori yang dapat menjabarkan fenomena dari isu lingkungan yang ada. Konsep politik lingkungan memiliki beragam istilah jika dilihat dari perspektif ilmu sosial, yang diantaranya ialah Political Ecology, Green Politics dan Environmental Politics (Winch et al., 1976). Dalam pembahasan mengenai politik lingkungan, maka akan mencakup beberapa hal di dalamnya. Hal yang akan dibahas dalam pembahasan mengenai politik lingkungan, antara lain: konflik agrarian, konflik kepentingan energi dan SDA, kerusakan lingkungan, ketahanan pangan, pencemaran lingkungan, manajemen bencana, konflik sengketa air, konflik industri, pengelolaan lingkungan antar aktor, konservasi ekologi, gerakan hijau, pemanasan global, konflikkonflik lingkungan, dll.

Ditinjau dari konteks politik, perihal keselamatan lingkungan akan menjadi pilihan agenda topik pembangunan apabila iklim demokrasi yang ada memberikan ruang gerak bagi isu-isu lingkungan dalam menempati agenda prioritas. Namun, di Indonesia isu-isu soal lingkungan belum menjadi topik utama dan prioritas dalam agenda pembangunan, bahkan cenderung menegasikan isu lingkungan. Prioritas agenda lingkungan akan tumbuh seiring dengan dibawanya wacana lingkungan oleh aktivis maupun akademisi pro lingkungan melalui pergerakan demokrasi hijau yang selanjutnya disebut sebagai eko demokrasi. (Rizal, Syafuan, \& Azrai, 2009) Artinya, pada tahap ini, iklim demokrasi akan mulai dipenuhi oleh wacana soal lingkungan dan menjadi atensi khusus dalam agenda prioritas nasional. Jika ditelusuri hubungan antara tambang dengan politik lingkungan, ada beberapa studi yang memberikan perhatian dalam fenomena ini. Salah satunya adalah David Hynmant dan Stuart (2003) yang mengatakan bahwa tambang telah melahirkan permasalahan lingkungan dan respon masyarakat terhadap krisis lingkungan tersebut disebut sebagai resistensi ekologi. Akibat permasalahan lingkungan akan berdampak pada ketimpangan rass dan kelas atas akses terhadap sumber daya lingkungan. Konflik pertambangan yang terjadi bukan semata-mata merupakan konflik lingkungan melainkan konflik berwajah banyak.(Erman, 2010) Selanjutnya dalam penelitian ini konflik yang terjadi adalah bagaimana dampak dari aktivitas pembakaran batu bara terhadap dampak lingkungan dan kehidupan masyarakat setempat yang bertempat tinggal dan bekerja di lingkungan PLTU Suralaya.

Dalam konteks politik lingkungan, ada beberapa aktor yang membangun relasi, yakni negara sebagai aktor langsung, dan masyarakat sipil sebagai aktor tidak langsung. Negara dikatakan sebagai aktor langsung didasarkan pada fungsinya sebagai pembentuk, pengimplementasi, pengelola, dan pengevaluasi kebijakan soal 
lingkungan. Negara lah yang bertanggung jawab secara langsung atas kontribusinya dalam pengelolaan permasalahahan lingkungan. Sementara masyarakat sipil sebagai aktor tidak langsung yang didalamnya ada LSM, akademisi, peneliti, organisasi lingkungan, dsb perlu memperhatikan dan mengawal permasalahan-permasalahan seputar lingkungan. Maka dalam pembahasan mengenai politik lingkungan, peran LSM dalam menanggapi isu-isu terkait permasalahan lingkungan menjadi sangat penting. Adapun salah satu LSM yang ikut serta dalam mengawal isu seputar permasalahan lingkungan yang menjadi topik pembahasan dalam penelitian ini adalah Trend Asia.

\section{Metode Penelitian}

Metode yang digunakan untuk penelitian ini yaitu metode kualitatif dengan pendekatan deskriptif. Metode ini digunakan karena dirasa relevan oleh peneliti untuk menyelesaikan fokus utama penelitian. Fokus dari penelitian ini ialah mengenai gerakan organisasi penggiat lingkungan dalam melakukan aksi penolakan, sehingga dalam menjawab segala permasalahan dalam penelitian ini digunakan analisis deskriptif yang bersumber dari data-data kualitatif. Pendekatan deskriptif yaitu penelitian yang meyajikan data berupa fakta sistematis dilakukan dengan cara menganalisis data yang ditemukan di lapangan. Data utama didapatkan dengan melakukan observasi lapangan serta melakukan wawancara langsung dengan salah satu anggota dari organisasi penggiat lingkungan yakni Trend Asia. Data pendukung dalam penelitian ini berupa bacaan ilmiah yang relevan dengan penelitian serta informasi-informasi yang diperoleh dari surat kabar maupun portal berita online.

\section{Hasil dan Diskusi}

Pada akhir tahun 2019, PLTU Suralaya kembali menambah unitnya untuk beroperasi menambah pasok listrik untuk Pulau Jawa, Madura dan Bali yang rencana pembangunannya mulai berjalan Januari 2020. Rencana pembangunan PLTU Suralaya shelter 9 dan 10 yang dikelola oleh Barito Pasifik dengan jumlah kapasitas 2X1000 Megawatt tentunya akan menambah dan mempengaruhi daya rusak lingkungan dan polusi udara bagi masyarakat Merak dan kemungkinan besar berdampak sampai wilayah Jakarta. Secara global emisi yang dihasilkan oleh PLTU dari pembakaran batu bara menyumbang sekitar 20\% emisi. Proyek pembangunan shelter 9 dan 10 PLTU Suralaya ini bertempat di Desa Salira, Merak, Banten yang mana posisinya tidak berjauhan dengan unit-unit PLTU Suralaya yang lainnya,

Berbagai macam penolakan beredar di lingkungan masyarakat dalam rangka mempertahankan kondisi lingkungan dan juga kesehatan masyarakat sekitar. Penolakan ini tidak terjadi bukan tanpa alasan. Proyek PLTU Suralaya sendiri sudah sering memberikan dampak negatif bagi lingkungan dan berdampak pula pada masyarakat. Proses pembakaran batu bara menjadi salah satu penyebab lingkungan Pantai Salira dan wilayah Desa Salira menjadi kotor akibat polusi udara, air dan juga tanah yang ditimbulkan. Selama bertahun-tahun, masyarakat Desa Salira dikelilingi dan dikepung oleh cerobong-cerobong PLTU yang terus mengeluarkan asapnya. Hal 
ini berdampak besar bagi ekosistem laut dan juga pemukiman penduduk. Para nelayan sekitar terhambat dalam kerjanya karena harus melaut semakin jauh yang mengakibatkan biaya ongkos mahal, hal tersebut diungkapkan oleh Bapak Salimudin selaku Ketua Rukun Nelayan Salira.

Di samping itu, Dinas Kesehatan Cilegon mencatat sebanyak 15.039 balita di Kota Cilegon berkunjung ke puskesmas dan rumah sakit akibat kesukaran bernapas yang diduga menderita ISPA. Hal ini diakibatkan oleh produksi pembakaran batu bara oleh PLTU Suralaya yang dilakukan secara terus menerus tanpa memperhatikan kesehatan masyarakat sekitar. Dikhawatirkan ketika PLTU Suralaya menambah unit yakni shelter 9 dan 10, maka dampak kesehatan yang buruk akan terus membayangi masyarakat sekitar.

Selama PLTU Suralaya beroperasi seringkali terjadi kebakaran tongkang pengangkut batu bara di laut lepas Salira. Salah satu yang paling besar dan menimbulkan dampak besar pula terjadi pada Agustus 2019. Menurut Trend Asia, salah satu lembaga swadaya masyarakat yang fokus akan isu lingkungan dan energi bersih melaporkan bahwa ada 7.510 ton batu bara yang terbakar diatas tongkang batu bara dekat lokasi proyek baru PLTU Suralaya yakni shelter 9 dan 10. Batu bara tersebut terbakar diatas tongkang tepat selama 16 hari yang mengakibatkan dampak besar bagi lingkungan dan kesehatan masyarakat. Dalam peristiwa kebakaran ini yang memberikan dampak amat buruk bagi lingkungan dan masyarakat, tidak mendapat perhatian dan tindakan dari pemerintah setempat yakni Pemerintah Kota Cilegon, yang menimbulkan keselamatan masyarakat terabaikan.

Polusi udara yang dihasilkan oleh PLTU berbahan dasar batubara dapat memberikan kerugian yang besar, baik dari segi pertanian, perikanan, lingkungan serta perekonomian masyarakat di sekitar lingkungan PLTU dan yang menjadi dampak utama dari polusi udara akibat pembakaran batubara ialah dapat menyebabkan gangguan kesehatan bagi manusia dan juga hewan. Dari berbagai macam dampak lingkungan dan kesehatan yang ditimbulkan oleh proyek PLTU Batu bara khsusunya PLTU Suralaya, maka alih-alih menambah unit yang baru seharusnya pemerintah menutup pembangkit listrik berbahan batu bara ini. Masyarakat berhak untuk dapat menghirup udara yang bersih dan segar yang menjadi tanggung jawab bagi pemerintah untuk mewujudkan hak mendasar tersebut. Jika pembangunan PLTU Suralaya sehter 9 dan 10 terus dilanjutkan maka berbagai macam dampak buruk lainnya akan terjadi seperti kontribusi signifikan terhadap emisi gas rumah kaca.

Dari berbagai macam dampak negatif dan merugikan bagi lingkungan dan masyarakat, masyarakat melakukan berbagai macam cara untuk menghentikan proyek pembangunan PLTU Suralaya shelter 9 dan 10 ini. Berangkat dari kesadaran masyarakat akibat dampak serius proyek pembakaran batu bara, maka masyarakat berbondong-bondong untuk melakukan gerakan penolakan. Gerakan ini tidak serta merta dilakukan oleh masyarakat seorang tapi juga dibantu oleh lembaga swadaya masyarakat yang fokus akan isu energi bersih yakni Trend Asia. Trend Asia sudah cukup lama mengikuti perkembangan proyek PLTU Suralaya yang begitu banyak menyumbang dampak buruk bagi ekosistem lingkungan dan kesehatan masyarakat. Hingga kini, Trend Asia masih konsisten untuk eksis terlibat bersama masyarakat 
melakukan gerakan penolakan terhadap pembangunan proyek baru PLTU Suralaya shelter 9 dan 10.

Gerakan yang diinisiasi oleh Trend Asia ini termasuk kedalam bentuk gerakan sosial baru dengan mengangkat isu lingkungan seperti yang dijabarkan oleh Singh; 2007 bahwa yang diperjuangkan dalam gerakan sosial baru ialah bersifat plural. Selaras dengan yang dijelaskan oleh Prasetya dan Suprayogi; 2019, kebebasan menjadi dasar dari lahirnya gerakan penolakan pembangunan unit tambahan PLTU Suralaya ini, dimana masyarakat ingin terbebas dari polusi yang dihasilkan oleh produksi listrik PLTU Suralaya yang terus menghantui setiap harinya. Dalam gerakan ini juga tidak terbirokratisasi dan tidak memiliki struktur karena inti dari gerakan berangkat dari individu-individu yang memiliki kepentingan serta kesamaan isu yang diperjuangkan yakni perihal lingkungan. Identitas politik yang tercipta dari partisipan-partisipan gerakan penolakan unit tambahan PLTU Suralaya berfokus pada upaya menekan pemerintahan untuk tidak mementingkan kepentingan material semata untuk tetap mempertahankan batu bara sebagai bahan utama produksi listrik disamping kesehatan masyarakat dan lingkungan. Apabila ditinjau dari perspektif politik lingkungan, maka gerakan yang dilakukan oleh Trend Asia merupakan gerakan yang mengangkat mengenai isu pencemaran lingkungan, dimana hal ini dapat dilihat dari dampak produksi PLTU yang menimbulkan begitu banyak polusi udara, tanah, dan air yang mencemari ekosistem lingkungan di sekitarnya.

Salah satu dari sekian upaya yang dilakukan Trend Asia bersama masyarakat ialah melakukan gerakan menolak aliran dana untuk pembangunan proyek 9 dan 10 PLTU Suralaya. Menurut Trend Asia sendiri yang dikemukakan oleh Ahmad Ashov Birru selaku juru kampanye Trend Asia, rencana pembangunan PLTU Suralaya shelter 9 dan 10 merupakan ide buruk yang harus dihentikan. Oleh karena itu masyarakat melakukan aksi demonstrasi untuk segera menghentikan aliran dana terhadap proyek pembangunan PLTU unit baru ini. Di mana aliran dana diperoleh melalui institusi keuangan korea yakni Korea Export Import Bank dan Korea Development Bank, kedua institusi keuangan tersebut bekerja sama dengan perusahaan konstruksi Korea Elecric Power Corporation (KEPCO) dan perusahaan Doosan Heavy.

Pada Januari 2020, Korea Development Institute (KDI) merilis hasil studi kelayakan awal atas proyek baru PLTU Suralaya shelter 9 dan 10. Dari hasil studi tersebut menjelaskan bahwa proyek emisi kotor ini minus. Sehingga Direktur KEPCO menunda pembahasan pendanaan pembangunan PLTU shelter 9 dan 10 ini. Menurut Direktur Eksekutif Trend Asia, Yuyun Indradi, membiayai proyek batu bara hanya akan meningkatkan resiko dan ancaman bagi kesehatan masyarakat dan lingkungan. Sudah seharusnya semua perusaahan asing pemodal sepertu KDB, KEXIM, dan K-Sure untuk membatalkan secara permanen keterlibatan mereka dalam proyek kotor ini.

Ditinjau dari konteks politik, perihal keselamatan lingkungan akan menjadi pilihan agenda topik pembangunan apabila iklim demokrasi yang ada memberikan ruang gerak bagi isu-isu lingkungan dalam menempati agenda prioritas. Namun, di Indonesia isu-isu soal lingkungan belum menjadi topik utama dan prioritas dalam agenda pembangunan, bahkan cenderung menegasikan isu lingkungan. Hal ini dapat dilihat dari kondisi pemerintah yang terus gencar melakukan proyek pembangunan 
PLTU Suralaya ini, padahal proyek emisi tinggi seperti PLTU ini tidak lagi diminati oleh lembaga pendana karena dampak lingkungan dan manusianya. Sementara apabila ditinjau dari perspektif politik lingkungan dimana ada aktor-aktor yang membangun relasi yakni Negara sebagai aktor langsung dan masyarakat sipil sebagai aktor tidak langsung, terdapat ketidakseimbangan dalam menjalankan fungsi relasi tersebut. Negara yang seharusnya memiliki peran strategis bertanggung jawab secara langsung atas kontribusinya dalam pengelolaan permasalahahan lingkungan, terlihat acuh atas permasalahan yang dialami oleh masyarakat dan lingkungan akibat dari dampak negatif produksi listrik PLTU Suralaya. Sementara masyarakat sipil sebagai aktor tidak langsung yang didalamnya terdapat LSM Trend Asia menjalankan perannya dengan baik dalam hal memperhatikan dan mengawal permasalahan-permasalahan seputar lingkungan pada kasus pembangunan shelter baru PLTU Suralaya.

Pembangunan proyek shelter 9 dan 10 harus dibatalkan demi menyelamatkan masyarakat karena paparan polusi di Banten dan Jakarta sangat berbahaya. Selain itu, masyarakat juga terus melakukan aksi protes karena dengan adanya ekspansi pembangunan PLTU batu bara ini akan terus memperburuk kualitas udara, air dan tanah di lingkungan mererka, serta tak luput juga dampak kesehatan masyarakat yang tinggal disana. Pembakaran batubara dapat mengganggu kesehatan bahkan kematian karena adanya partikel PM2.5 yang dibentuk dari nitrogen oksida, debu dan emisi sulfur. Partikel PM2.5 merupakan partikel-partikel halus yang dapat masuk ke aliran darah dan paru-paru Selain itu juga mengganggu kesehatan manusia disebabkan oleh paparan dari bahan-bahan beracun, logam berat dan juga ozon. Jika rencana eskpansi pembangunan ini tetap dilakukan oleh pemerintah dan kemudian beroperasi, maka dipresdiksi akan mengakibatkan 4.700 kematian disi selama 20 tahun masa operasi PLTU Suralaya. Namun angka ini bisa ditekan apabila pemerintah Korea berkeinginan untuk menghentikan lembaga keuangan publiknya untuk berinvestasi di proyek energi batu bara ini.

Maka dari itu untuk menghentikan proyek pembangunan PLTU Suralaya shelter 9 dan 10 masyarakat bersama dengan Trend Asia terus menggagas berbagai macam langkah dan gerakan untuk tercapainya tujuan mereka. Ditambah, kini pembangunan proyek ini beserta dampak lingkungannya telah menjadi perhatian dunia. Sehingga Trend Asia pun gencar melakukan aksi-aksi dokumentasi melalui media sosial dan juga media konvensional yang menerangkan kondisi masyarakat dan lingkungan akibat dampak buruk proyek PLTU Suralaya. aksi gerakan penolakan pembangunan Shelter 9 dan 10 PLTU Suralaya ini dilakukan Trend Asia bersama-sama dengan masyrakat kota Cilegon, yang juga dibantu oleh organisasi masyarakat sipil Korea. Gerakan penolakan yang dilakukan oleh Trend Asia bersama dengan Masyarakat Suralaya ialah dengan membuat petisi, serta melakukan gugatan hukum di pengadilan Korea yang difasilitasi oleh organisasi masyarakat sipil Korea.

Ada berbagai macam rekomendasi bagi pemerintah agar proyek PLTU batu bara tidak semakin menambah jerat kasus lingkungan dan dampak buruk bagi masyarakat, diantaranya:

1. Tidak ada lagi pembangunan unit PLTU baru. 
2. Menutup PLTU tertua dan terkotor yang sangat mempengaruhi dampak lingkungan,

3. Memperkuat aturan hukum dan pengakannya terkait polusi yang ditimbulkan PLTU batu bara.

4. Meningkatkan energi terbarukan seperti energi panas bumi.

5. Pemerintah pusat maupun daerah perlu memiliki komitmen untukmengatasi perubahan iklim dengan mengurangi emisi gas rumah kaca yang ditimbulkan oleh PLTU batu bara.

Pada akhirnya Perlu adanya deregulasi serta penghentian promosi mengenai pembangkit listrik tenaga batubara di Indonesia. sebagai bahan dasar pemasok listrik. Karena Indonesia akan melawan trend global yang tidak lagi meminati batu bara sebagai bahan utama produksi listrik sehingga Indonesia akan terus terjebak mengabaikan kondisi kesehatan rakyatnya serta ekosistem lingkungan. Selain itu pemerintah harus tetap memiliki komitmen akan janjinya untuk mengurangi emisi gas rumah kaca di Indonesia.

\section{Kesimpulan}

Pengoperasian pembangunan PLTU shelter 9 dan 10 di Suralaya Merak - Banten menuai berbagai macam penolakan oleh banyak pihak, bahkan hingga disoroti oleh media internasional. Namun hal ini tidak menjadi perhatian utama oleh pemerintah Indonesia sendiri. Hal ini menunjukkan perlunya perubahan terhadap kebijakan terkait dengan kondisi lingkungan hidup yang aman, nyaman dan sejahtara untuk masyarakat dan daerah. Sehingga memberikan keseimbangan terhadap ekosistem lingkungan.

Trend Asia sebagai NGO yang mendukung penolakan keberlangsungan pembangunan PLTU shelter 9 dan 10 di Suralaya Merak-Banten telah berulangkali memberikan himbauan dan kampanye pemberhentian pembangunan sebagai upaya penolakan. Masyarakat setempat juga menjadi korban utama atas dampak dari operasi pembangunan ini. Diharapakan dengan adanya penelitian ini menjadi bahan pertimbangan tindak lanjut kepada pemerintah daerah atau pemerintah pusat dalam memberikan solusi mengenai permasalahan yang disebabkan oleh pembangunan PLTU Shelter 9 dan 10 di Suralaya Merak-Banten. Meskipun gerakan penolakan yang dilakukan oleh masyarakat Suralaya dan Banten secara umum masih sangat sedikit dan kurang massif dilakukan.

\section{Tentang Penulis}

Nida Urrohmah merupakan mahasiswa di ilmu pemerintahan Universitas Sultan Ageng Tirtayasa. Dengan peminatan penulis kepada kajian politik lingkungan, membuat penulis mencoba mengelaborasi terhadap isu-isu dalam politik lingkungan.

Karin Caroline Kelly merupakan mahasiswa di ilmu pemerintahan Universitas Sultan Ageng Tirtayasa. Dengan peminatan penulis kepada kajian politik lingkungan, membuat penulis mencoba mengelaborasi terhadap isu-isu dalam politik lingkungan. 
Fitri Yuliani merupakan mahasiswa di ilmu pemerintahan Universitas Sultan Ageng Tirtayasa. Dengan peminatan penulis kepada kajian politik lingkungan, membuat penulis mencoba mengelaborasi terhadap isu-isu dalam politik lingkungan.

\section{Ucapan Terimakasih}

Penulis mengucapkan terimaksih kepada dosen-dosen pembimbing di ilmu pemerintahan Universitas Sultan Ageng Tirtayasa. Terimakasih juga kepada semua phak yang telah membantu dan membuat penelitian ini menjadi sebuah artikel yang baik untuk dapat di terbitkan.

\section{Referensi}

Arefana, P. (2019). Abu Limbah PLTU Suralaya Banten Be terbangan, Warga Sekitar Resah. Diperoleh dari suarabanten.id pada 16 Maret 2020:

https:// banten.suara.com/amp/read/2019/11/29/085900/abu-pltu-suralaya-bantenbeterbangan-ancam-nyawa-balita

Bakoro, Galih Honggo. (2013). PLTU Batubara: Antara Solusi Krisis Listrik dengan Isu Pencemaran Lingkungan (Studi Kasus Pada PT PLN (Persero) Unit Pembangkitan Jawa Bali). Jurnal General Bussines Environment Vol 1 No 2.

CNN Indonesia. (2019). Warga Banten Minta Korsel Hentikan Pendanaan PLTU Jawa 9. Diperoleh dari CNN Indonesia pada 16 Maret:

https:// www.cnnindonesia.com/nasional/20190829221805-20-425949/warga-bantenminta-korsel-hentikan-pendanaan-pltu-jawa-9

Erman, E (2010). Aktor, akses dan politik lingkungan di pertambangan timah Bangka. Masyarakat Indonesia, 36(2), 71-101. https:// doi.org/10.14203/jmi.v36i2.640.

Feretic, D., dan Tomsic, Z. (2005). Probabilistic analysis of electrical energy costs comparing: Production costs for gas, coal and nuclear power plants. Energy Policy, 33(1), 5-13. https://doi.org/10.1016/S0301-4215(03)00184-8

Greenpeace. (2015). Human Cost of Coal Power: How Coal-Fired Power Plants Threaten the Health of Indonesians. August, 1-32.

Tempo. (2018). PLTU Siralaya Tak Miliki Izin Pengelolaan Limbah. Diperoleh dari Koran Tempo pada 16 Maret: https://koran.tempo.co/read/nusa/18414/pltu-suralayatak-miliki-izin-pengelolaan-limbah

Moleong, Lexy J. (2007). Metodologi Penelitian Kualitatif. Bandung: PT Remaja Rosda Karya Offset.

Prasetya, Andina dan Yogi Suprayogi. (2019). Isu Gerakan Sosial Baru: Tempat Nasi Gratis Bandung. Jurnal Pemikiran dan Penelitian Sosiologi. Vol. 3. No. 2 
Ruzal, M. Y., Syafuan, R., dan Azrai, H. A. (2009). A Caleidoscope of Environmental Security: Indonesian and Malaysian Perspectives. Jakarta: Madani Press.

S. Julianti, dan Jamaluddin, Amiruddin. (2018). Dampak Keberadaan Pembangkit Listrik Tenaga Uap (PLTU) Terhadap Kondisi Sosial Ekonomi Masyarakat di Kelurahan Panau Kecamatan Tawaili. Jurnal Elektronik Geo Tadakulo Vol. 6 No. 2

Singh, Rejedra. (2007). Gerakan Sosial

Baru. Penerjemah

Eko P. Darmawan. Yogyakarta: Resist Book.

Situmorang, dan Wahib, A. (2007). Gerakan Sosial: Teori dan Praktik. Yogyakarta: Pustaka Pelajar.

Suharko. (2006). Gerakan Sosial Baru di Indonesia: Repertoar Gerakan Petani. Jurnal Ilmu Sosial dan Ilmu Politik Vol. 10 No. 1

Winch,D.M.,Baumol, W. J., dan Oates,W. E.(1976).The Theory of Environmental Policy.The Canadian Journal of Economics,9(1), 200. https:/ / doi.org/10.2307/134432

Xue,Z.,Hao, J.,Chai,F.,Duan,N.,Chen,Y.,Li, J.Chen,F.,Liu, S.,dan Pu, W. (2005). Air Quality Impact of the Coal-Fired Power Plants in the Northern Passageway of the China West-East Power Transmission Project. Journal of the Air and Waste Management Association, 55(12),

https:/ / doi.org/10.1080/10473289.2005.10464781 